\title{
Validation of Housekeeping Genes as Internal Control for Studying Gene Expression in Rhododendron Molle G. Don Located on Dabie Mountains
}

Zhang Yujia, Shu Du, Dong Xue, Du Ruichen, Li Zhiliang, Wang Shuzhen $\square$

Hubei Collaborative Innovation Center for the Characteristic Resources Exploitation of Dabie Mountains, College of Life Science, Huanggang Normal University, Huanggang, 438000, China

$\checkmark$ Corresponding author email: wangshuzhen710@,whu.edu.cn

Tree Genetics and Molecular Breeding, 2020, Vol.10, No.3 doi: $10.5376 /$ tgmb.2020.10.0003

Received: 25 Jul., 2020

Accepted: 27 Jul., 2020

Published: 07 Aug., 2020

Copyright @ 2020 Zhang et al., This article was first published in Molecular Plant Breeding in Chinese, and here was authorized to translate and publish the paper in English under the terms of Creative Commons Attribution License, which permits unrestricted use, distribution, and reproduction in any medium, provided the original work is properly cited.

Preferred citation for this article:

Zhang Y.J., Shu D., Dong X., Du R.C., Li Z.L., and Wang S.Z., 2020, Validation of housekeeping genes as internal control for studying gene expression in Rhododendron Molle G. Don located on Dabie Mountains, Tree Genetics and Molecular Breeding, 10(3): 1-7 (doi: 10.5376/tgmb.2020.10.0003)

\begin{abstract}
Rhododendron molle G. Don, a member of the family of Rhododendron, possesses high ornamental and medicinal value. As a species specific to Dabie Mountains, its distribution was scattered. The estimation of expression stability of internal reference genes was vital for molecular biological and genetic research. In this study, expression pattern of candidate genes RmRPL3-1, RmNAC-1, RmCOX1-4, RmRmPDS-1, RmUBQ-6, and RmL10-4 were analyzed in different tissues of R. molle by real-time quantitative RT-PCR, including root, stem, leaf, and flower. According to GeNorm, NormFinder, and Best-keepersoftwares, the most stable internal reference in different tissues of $R$. molle was the combination of RmCOX1-4 and RmUBQ-6. The most stable internal reference genes selected in this study will provide a basis for the following gene expression study in $R$. molle.
\end{abstract} Keywords Rhododendron molle G. Don; Reference genes; qRT-PCR; Expression pattern

Rhododendron molle G. Don, also known as goat blossom and lamb staggering, belongs to the genus of Rhododendron (Ericaceae), which is mainly distributed along the Yangtze River (Zhou et al., 2017). R. molle, having large crown and funnel-shaped flower, is a specific ornamental species unique to China. Moreover, $R$. molle also has extremely high medicinal value in treating rheumatoid arthritis, injury, enhancing muscles, activating collaterals. Due to strong insecticidal efficacy, the flowers, leaves, and branches have been traditionally used in forestry protection (Klocke et al., 1991; Chen and Hu, 1999). Recently, more research were focused on rapid propagation in vitro, clarification of insecticidal mechanism, and genetic diversity of the green pesticide $R$. molle, but less on analysis of gene expression profiling ( $\mathrm{Li}$ et al., 2018; Xiao et al., 2018).

As a common technique in molecular biology, quantitative real time-fluorescence polymerase chain reaction (qRT-PCR) was widely used in the quantitative analysis of target genes due to the characteristics of high sensitivity, good accuracy, strong specificity, simple operation, rapid, and efficient (Xiao et al., 2016). However, stable internal reference genes were critical for the qRT-PCR amplification, which could eliminate errors generated during qRT-PCR process (Fan et al., 2018). The best reference genes are housekeeping genes, whose expression level was never affected by tissue types, developmental stages, and external factors (Bustin and Nolan, 2004; Han et al., 2012). However, expression patterns of genes are diverse, as functions of genes are different in different tissues, at different developmental stages, and even under various environments (Tashiro et al., 2016; Song et al., 2017). Therefore, before studying the dynamic expression pattern of target genes, it is necessary to evaluate the stability of candidate reference genes according to specific experimental conditions and plant development stage, select the reference genes with the most stable expression level, so as to maximize the accuracy of quantitative gene research. In this study, six candidate internal reference genes were validated in different tissue of $R$. molle (root, stem, leaf, and flower), a species specific to Dabie Mountains. The most stable internal reference in different tissues were screened out according to GeNorm, NormFinder, and Best-keeper softwares, which will provide a basis for the following gene expression study in $R$. molle. 


\section{Results and Analysis}

\subsection{Quality detection of total RNA in root, stem, leaf, and flower of $R$. molle}

Total RNA was extracted from root, stem, leaf, and flower of $R$. molle, and was analyzed by agarose gelelectrophoresis. The bands of 28SrRNA and 18SrRNA were very intact, and the brightness of 28SrRNA was twice of that of $18 \mathrm{SrRNA}$ without obvious RNA degradation or genomic DNA contamination. The OD260/OD280 ratios of four tissue RNA samples were all within the range of $1.8 \sim 2.0$ by ultraviole visible spectrophotometer, indicating that the purity of total RNA was high enough for subsequent qRT-PCR amplification (Figure 1).

\subsection{Evaluation of candidate reference gene}

The size of amplification products of six candidate reference genes ranged from $200 \mathrm{bp}$ to $230 \mathrm{bp}$, and annealing temperature for these specific primer pairs was within the range of $52^{\circ} \mathrm{C} \sim 60^{\circ} \mathrm{C}$. DNA pool was mixed with equal portions of DNA extracted from root, stem, leaf, and flower. Then, PCR amplification was performed with the DNA pool to validate the specificity of primer pairs. Results showed that length of the amplified products was consistent with the expectation, and all were single bands without non-specific amplification. The expression level of these six candidate genes was stable in root, stem, leaf and flower tissue. The melting curve showed the specific expression of six candidate genes, and specific bands were also detected in agarose gel electrophoresis. The linear correlation coefficients $\mathrm{R}^{2}$ calculated according to the standard curve were all greater than 0.99 , and the amplification efficiency ranged from $95.0 \%$ to $105.0 \%$. These primer pairs met the requirements of qRT-PCR, which could be used for stability evaluation of reference genes (Table 1).

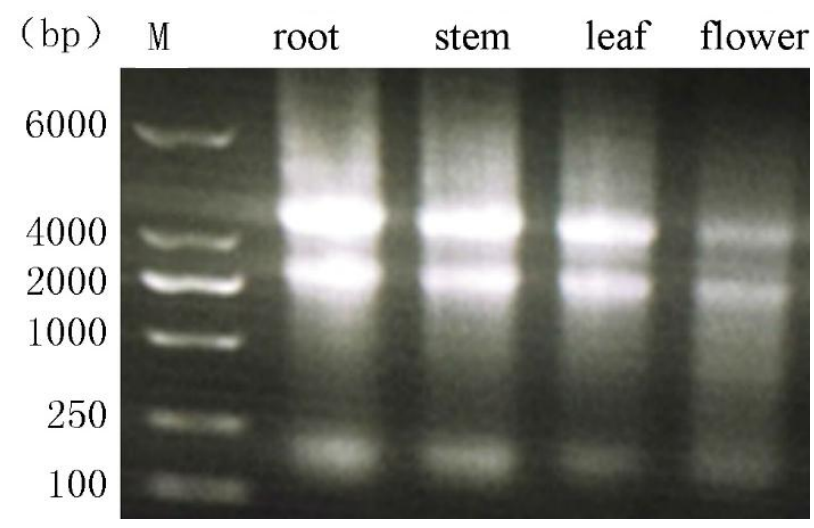

Figure 1 RNA extracted from four different tissues of $R$. molle

Table 1 Primer information of six reference genes

\begin{tabular}{llllll}
\hline Gene name & Forward/Reverse primer sequence $\left(5^{\prime}-3^{\prime}\right)$ & $\begin{array}{l}\text { Annealing } \\
\text { temperature }\left({ }^{\circ} \mathrm{C}\right)\end{array}$ & $\begin{array}{l}\text { Product } \\
\text { length }(\mathrm{bp})\end{array}$ & $\begin{array}{l}\text { Amplification } \\
\text { efficiency }(\%)\end{array}$ & $\begin{array}{l}\text { Correlation coefficient } \\
\left(\mathrm{R}^{2}\right)\end{array}$ \\
\hline$R m C O X 1$ & $\begin{array}{l}\text { F:GGTCCGTTCTAGTGACAGCA } \\
\text { R:GATACCGGATCCAGGCAGAA }\end{array}$ & 60 & 203 & 103.05 & 0.994 \\
$R m N A C-1$ & $\begin{array}{l}\text { F:TGGAACTCGGAAGCGTAGAA } \\
\text { R:TTCTCCAGTGCCCAAGTGAT }\end{array}$ & 58 & 205 & 99.76 & 0.992 \\
$R m P D S-1$ & $\begin{array}{l}\text { F:ACGAATTGCTTGCTTCCCG } \\
\text { R:GCACTCTTAGGGATTCGCTGTC }\end{array}$ & 57 & 216 & 101.12 & 0.995 \\
$R m U B Q-6$ & $\begin{array}{l}\text { F:TGTGAAGACTCTTACTGGGAAG } \\
\text { R:CTCCCATCCTCCAACTGCTT }\end{array}$ & 60 & 229 & 98.69 & 0.997 \\
$R m L 10-4$ & $\begin{array}{l}\text { F:AGCAGGGAAGACGAAGATCA } \\
\text { R:TAGCCAAGCGTTCATACCCT }\end{array}$ & 52 & 220 & 99.24 & 0.994 \\
& $\begin{array}{l}\text { F:CATCTGAGCGAGGAGGTGAA } \\
\text { R:GGTGTGCCTTCTTCTGCTTC }\end{array}$ & 58 & 217 & 99.73 & 0.996 \\
\hline
\end{tabular}




\subsection{Expression level of candidate reference genes}

The $C t$ values of $R m C O X 1$ ranged between 21.15 and 26.41 in different tissues, with the mean value of 22.97. In particular, the maximum $C t$ value of $R m C O X 1$ was observed in stem, while the minimum value was in leaf. $C t$ values of $R m N A C-1$ ranged from 21.80 (stem) to 28.95 (flower) with the mean $C t$ value of 24.05. Moreover, $C t$ values of $R m L 10$ ranged from 31.21 (root) to 32.87 (stem) with the mean value of 32.04. The $C t$ values of $R m P D S-1$ and $R m U B Q-6$ were within ranges of $20.73 \sim 27.46$ and $30.42 \sim 35.11$, with the average value of 23.36 and 31.76, respectively. $C t$ values of RmRPL3 varied from 20.57 to 27.11 , with the mean value of 22.68. In related to candidate reference gene $R m P D S-1, R m U B Q-6$, and $R m R P L 3$, the maximum $C t$ value was observed in the stem and the minimum $C t$ value existed in flower.

\subsection{Expression stability of the candidate reference genes}

Analyzing the stability of six candidate reference genes with geNorm, the $C t$ value was converted into relative expression quantity $\mathrm{Q}$, which was used to calculate the expression stability $\mathrm{M}$. The smaller the $\mathrm{M}$ value, the higher the stability of the internal reference gene (Stamova et al., 2009). The expression stability (from high to low) of the six candidate genes was as follow: RmRPL3-1=RmNAC-1>RmCOX1-4>RmPDS-1>RmUBQ-6>RmL10-4. The optimal genes screened were the combination of RmRPL3-1 and RmNAC-1, while the worst was RmL10-4 (Figure 2; Table 2).

The geNorm software was also used to calculate the paired difference value $\mathrm{V}$, which could determine the optimal number of internal reference genes. Results showed that the threshold value of the paired difference value was 0.15 . If $\mathrm{Vn} / \mathrm{n}+1$ was less than $0.15, \mathrm{n}+1$ internal reference gene were needed to correct the expression of the target gene (Jiang et al., 2017). In this study, the $\mathrm{V}_{2 / 3}, \mathrm{~V}_{3 / 4}, \mathrm{~V}_{4 / 5}$ and $\mathrm{V}_{5 / 6}$ were all greater than 0.15 , as they were $0.315,0.214,0.207$ and 0.543 , respectively. Therefore, the combination number of suitable reference genes should be determined by classification.

Normfinder software was used to calculate the stable expression value (S) of candidate reference genes. Lower $\mathrm{S}$ values means higher stability (Michael et al., 2004). The $\mathrm{S}$ values of the six candidate reference genes ranged from 0.22 to 2.25. RmUBQ-6 gene had the lowest $\mathrm{S}$ value but was the most stable reference gene. However, the highest $\mathrm{S}$ value and the least stable gene was $R m L 10-4$. According to the $\mathrm{S}$ value, stability of the six candidate internal reference genes was as follow: $R m U B Q-6>R m C O X-1>R m R P L 3-1>R m P D S-1>R m N A C-1>R m L 10-4$ (Table 2). In particular, the stability of RmL10-4 was the worst expression in different tissues both in geNorm and Normfinder analysis, which was not suitable for study on gene expression.

By the Bestkeeper software, the stability of reference genes were selected according to the SD and CV of $C t$ values, as well as coefficient of correlation (r) and its index. The most stably expressed reference gene had the $C t$ value with lowest SD and CV values. Genes with SD value less than 1 are suitable for internal reference genes (Yan et al., 2015). The candidate internal reference gene with high expression stability was RmL10-4 $(\mathrm{SD}=0.61)$, while stability of $R m N A C-1(\mathrm{SD}=2.451)$ was the lowest (Table 2).

According to GeNorm, NormFinder, and Best-keeper softwares, the most stable internal reference in different tissues of $R$. molle was the combination of RmCOX1-4 and RmUBQ-6, followed by RmRPL3-1. The worst reference gene were RmL10-4 and RmNAC-1.

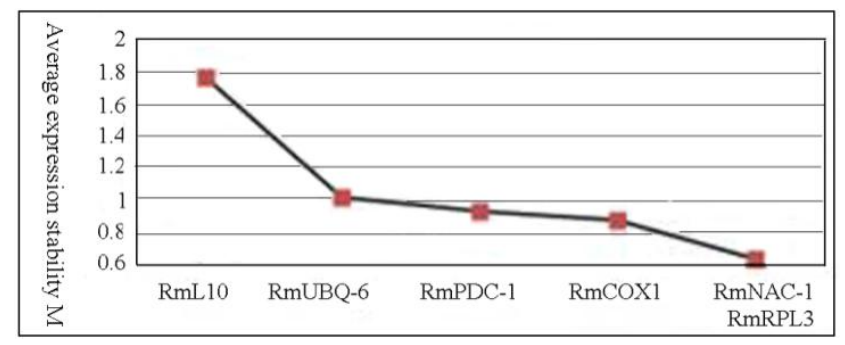

Figure 2 Expression stability of candidate reference genes in different tissues based on Genorm software 
Tree Genetics and Molecular Breeding 2020, Vol.10, No.3, 1-7

http://genbreedpublisher.com/index.php/tgmb

Table 2 Stability ranking of six candidate reference genes in different tissues

\begin{tabular}{llll}
\hline No. & GeNorm ranking & NormFinder ranking & BestKeeper ranking \\
\hline 1 & $R m R P L 3-1$ & $R m U B Q-6(\mathrm{~S}=0.224)$ & $R m L 10-4(\mathrm{SD}=0.61 ; \mathrm{CV}=1.91)$ \\
2 & $R m N A C-1$ & $R m C O X 1-4(\mathrm{~S}=0.304)$ & $R m U B Q-6(\mathrm{SD}=1.68 ; \mathrm{CV}=5.29)$ \\
3 & $R m C O X 1-4$ & $R m R P L 3-1(\mathrm{~S}=0.554)$ & $R m C O X 1-4(\mathrm{SD}=1.72 ; \mathrm{CV}=7.51)$ \\
4 & $R m P D S-1$ & $R m P D S-1(\mathrm{~S}=0.688)$ & $R m R P L 3-1(\mathrm{SD}=2.22 ; \mathrm{CV}=9.78)$ \\
5 & $R m U B Q-6$ & $R m N A C-1(\mathrm{~S}=0.804)$ & $R m P D S-1(\mathrm{SD}=2.33 ; \mathrm{CV}=9.98)$ \\
6 & $R m L 10-4$ & $R m L 10-4(\mathrm{~S}=2.247)$ & $R m N A C-1(\mathrm{SD}=2.45 ; \mathrm{CV}=10.20)$ \\
\hline
\end{tabular}

\section{Discussion}

In this study, expression pattern of candidate genes RmRPL3-1, RmNAC-1, RmCOX1-4, RmRmPDS-1, RmUBQ-6, and RmL10-4 were analyzed in different tissues (root, stem, leaf, and flower) of $R$. molle by real-time quantitative RT-PCR. Lengths of actin and 18S rRNA genes achieved from transcriptome data were $325 \mathrm{bp}$ and $289 \mathrm{bp}$, respectively. No clear target bands were obtained even more than ten times had been tried. Therefore, Actin and 18S rRNA genes were not considered in the validation of candidate reference genes. At present, geNorm, NormFinder and BestKeeper were the most effective analysis software to evaluate the stability of reference genes, though they used different statistical methods. Therefore, comprehensive analysis is needed to screen the most suitable internal reference genes (Hu et al., 2010; Ponton et al., 2011). According to these three software, stable internal reference genes have been validated from Chrysanthemum lavandulifo lium, Zanthoxylum bungeanum, Robinia pseudoacacia L., Hemarthria compressa, and Ginkgo biloba (Fei et al., 2018; Lin et al., 2019; Su et al., 2019).

Species belonging to Rhododendron play important roles in landscaping. However, research on molecular biology and genetics were limited, especially the validation of candidate reference genes. In Rhododendron delavayi Franch., the expression stability of 11 candidate reference genes (GAPDH, Tubulina-5, Ubiquitin, Actin, EF1a, UEP, UEC11, UEC2, Tubulin beta, TATA-binding protein, TIP41-LIKE FAMILYPROTEIN) were validated in leaves at different developmental stages and under drought stress with qBASE and NormFinder software (Zhang, 2019).

In this study, six candidate internal reference genes of $R$. mole were validated in different tissues. With geNorm software, the most stable genes were RmRPL3-1 and RmNAC-1, while the worst was RmL10-4. Meanwhile, expression stability of $R m U B Q-6$ was most stable with Normfinder analysis, but ranked five by geNorm analysis. Stability of RmL10-4 varied greatly with geNorm, Normfinder, and Bestkeeper. Bestkeeper software showed that the expression stability of RmNAC-1 was low, which was consistent with the results of Normfinder software.

In other research, stability of candidate reference genes also differed with different software, which might be caused by the different counting principles and methods of each software. Therefore, comprehensive analysis with several softwares should be performed to screen the best reference genes for gene expression profile analysis. Frequently, method of weighted assignment are adopted (Wang et al., 2019). According to GeNorm, NormFinder, and Best-keeper softwares, the most stable internal reference in different tissues of $R$. molle was the combination of RmCOX1-4 and RmUBQ-6, while the worst was RmPDS-1.

In the research on gene expression profile of peach trees, reference gene $U B Q 10$ was the best, while $R P L 13$ was the least (Tong et al., 2009). The best reference gene was $R m U B Q-6$, while the poorest one was RmRPL3-1, which was consistent with the research of Tong et al. (2009).

$R P L$ was the most stable reference gene in Lablab purpureus (Linn.) Sweet under abiotic stress (Ragini et al., 2019), but was not the suitable reference gene in molecular biology study of different tissues of $R$. molle. Moreover, $C O X$ was the most stable internal reference gene of Chlamydomonas rinhardtii under different culture conditions (Zhang, 2013). Similarly, stable expression of COX was also observed in different tissues of 
R. molle. Reference genes vary greatly in different varieties, different tissue parts, at different developmental stages, and under different treatment conditions. Therefore, it is necessary to validate the expression stability of internal reference genes before used in quantitative analysis of gene expression.

\section{Materials and Methods}

\subsection{Materials}

A 10-year-old $R$. molle plant was selected, which is preserved in the Rhododendron germplasm resource garden of Huanggang Normal University. During full flowering stage, fresh roots, stems, leaves, and flowers were collected and conserved at $-80^{\circ} \mathrm{C}$ for further use.

\subsection{Extraction of total RNA and first-strand cDNA synthesis}

Total RNA was extracted from roots, stems, leaves and flowers of $R$. molle with Plant RNA kit (OMEGA), and the quality and concentration were determined by UV spectrophotometer and agarose gel electrophoresis. The qualified RNA samples were reverse transcribed into first-strand cDNA with Reverse Transcriptase M-MLA (Takara, Dalian) and stored at $-20^{\circ} \mathrm{C}$ for further use.

\subsection{Amplification of candidate internal reference genes and screening of gene-specific primers}

Based on $R$. molle petal transcriptome data (NCBI accession number: SRR5247114), six candidate housekeeping genes were selected, including RmRPL3, RmNAC-1, RmCOX1, RmPDS-1, RmUBQ-6, and RmL10. The online software Primer 3.0 was used to design primer pairs in in conservative gene region according to primer design principle of qRT-PCR. The cDNA pool was prepared by mixing different cDNA with equal proportion. After serial 2-fold dilutions (1/2, 1/4, 1/8, 1/16, 1/32, 1/64, 1/128), these cDNA templates were used to verify gene-specific primer pairs. PCR amplification products were separated by $2 \%$ agarose gel electrophoresis. Primer pairs with specific amplification and clear amplification products were screened out.

\subsection{Analysis of expression level of candidate internal reference genes}

The 10-fold diluted cDNA samples of roots, stems, leaves and flowers of $R$. molle were used as templates for qRT-PCR amplification. Particularly, $10 \mu \mathrm{L}$ qRT-PCR reaction system was set: $5 \mu \mathrm{L} 2 \times$ SYBR Premix Ex $\mathrm{Taq}^{\mathrm{TM}}$ fluorescent dye (Takara), $2 \mu \mathrm{L}$ of cDNA templates, $0.4 \mu \mathrm{L}(10 \mu \mathrm{M})$ of each primer, and $0.2 \mu \mathrm{L}$ of ROX Reference Dye, and $2.4 \mu \mathrm{L}$ sterilized deionized water. The thermal conditions included initial denaturation at $95^{\circ} \mathrm{C}$ for $10 \mathrm{~min}, 40 \mathrm{cycles}\left(95^{\circ} \mathrm{C}\right.$ for $15 \mathrm{sec}, 60^{\circ} \mathrm{C}$ for $\left.60 \mathrm{sec}\right)$, and $1 \mathrm{cycle}\left(95^{\circ} \mathrm{C}\right.$ for $30 \mathrm{sec}, 60^{\circ} \mathrm{C}$ for $\left.15 \mathrm{sec}\right)$. In addition, melting curve was programmed to test the expected amplification product at $60^{\circ} \mathrm{C} \sim 95^{\circ} \mathrm{C}$. All experiments were performed three times for eliminating handling error.

\subsection{Comprehensive evaluation of the stability of candidate reference genes}

GeNorm, NormFinder, and Best-keeper softwares were used to evaluate the stability of six candidate reference genes. In particular, the $C t$ value was calculated directly by BestKeeper. However, the transformed value $\left(\mathrm{Q}=\mathrm{E}^{-(C t \text { sample- } C t \mathrm{~min})}\right)$ was adopted by GeNorm and NormFinder. Combing these calculating results, the suitable reference genes were screened.

\section{Authors' contributions}

Zhang Yujia and Wang Shuzhen were executors of experimental design and the experiment. Shu Du, Dong Xue, and Du Ruichen performed data analysis, and wrote the draft paper. Li Zhiliang participated in experimental design and analysis of the experimental results. Wang Shuzhen was in charge of the project, guided experimental design, performed data analysis, and corrected the paper. All authors read and approved the final manuscript.

\section{Acknowledgments}

This research was granted by funds from the National Natural Science Foundation of China (NSFC 31500995) and Hubei Intellectual Property Bureau (2019-1-35). 


\section{Reference}

Bustin S.A., and Nolan T., 2004, Pitfalls of quantitative real-time reverse-transcription polymerase chain reaction, J. Biomol. Tech., 15(3): 155-166

Chen D.M., and Hu M.Y., 1999, Research advances in the research on Rhododendron Molle G.Don, Tianranchanwu Yanjiu Yu Kaifa (Natural Product Research and Development), 11(5): 109-113

Fan L.J., Chen M.Q., Dong B., Wang N.H., Yu Q., Wang X.L., Xuan L.J., Wang Y.L., Zhang S.Z., and Shen Y.M., 2018, Transcriptomic analysis of flower bud differentiation in Magnolia sinostellaia, Genes, 9(4): 212

https://doi.org/10.3390/genes9040212

PMid:29659525 PMCid:PMC5924554

Fei X.T., Shi Q.Q., Yang T.X., Fei Z.X., and Wei A.Z., 2018, Expression stabilities of ten candidate reference genes for RT-qPCR in Zanthoxylum bungeanum Maxim, Molecules, 23(4): 802

https://doi.org/10.3390/molecules23040802

PMid:29601541 PMCid:PMC6017173

Han X.J., Lu M.Z., Chen Y.C., Zhan Z.Y., Cui Q.Q., and Wang Y.D., 2012, Selection of reliable reference genes for gene expression studies using real-time PCR in tung tree during seed development, PLoS ONE, 7(8):e43084

https://doi.org/10.1371/journal.pone.0043084

PMid:22912794 PMCid:PMC3422230

Hu R., Qi G., Kong Y.Z., Gao Q., and Zhou G.K., 2010, Compre hensive analysis of NAC domain transcription factor gene family in Populus trichocarpa, BMC Plant Biol., 10(1): 145

https://doi.org/10.1186/1471-2229-10-145

PMid:20630103 PMCid:PMC3017804

Jiang J., Wang Y.L., Zhao L.P., Zhou R., Li Y.R., Zhao T.M., and Yu W.G., 2017, Selection of tomato reference genes for qRT-PCR, Jiangsu Nongye Xuebao (Jiangsu Journal of Agricultural Sciences), 33(2): 389-396

Klocke J.A., Hu M.Y., Chiu S.F., and Kubo I., 1991, Grayanoid diterpene insect antifeedants and insecticides from Rhododendron molle, Phytochemistry, 30(6): 1797-1800 https://doi.org/10.1016/0031-9422(91)85015-R

LiY., Zhu Y.X., Zhang Z.X., Liu Y.L., Liu Y.B., Qu J., Ma S.G., Wang X.J., and Yu S.S., 2018, Diterpenoids from the fruits of Rhododendron molle, potent analgesics for acute pain, Tetrahedron, 74(7): 693-699 https://doi.org/10.1016/j.tet.2017.12.017

Lin Y., Zhang A.L., Yang S.T., and Huang L.K., 2019, Reference gene selection for real-time quantitative pcr normalization in Hemarthria compressa and Hemarthria altissima leaf tissue, Mol. Biol. Rep., 46(5): 4763-4769

https://doi.org/10.1007/s11033-019-04922-4

PMid:31228043

Michael W.P., Ales T., Christian P., and Neuvians T.P., 2004, Determination of stable housekeeping genes, differentially regulated target genes and sample integrity: BestKeeper-Excel-based tool using pair-wise correlations, Biotechnol. Lett., 26(6): 509-515

https://doi.org/10.1023/B:BILE.0000019559.84305.47

PMid: 15127793

Ponton F., Chapuis M.P., Pernice M., Sword G.A., and Simpson S.J., 2011, Evaluation of potential reference genes for reverse transcription-qPCR studies of physiological responses in Drosophila melanogaster, J. Insect. Physiol., 57(6): 840-850

https://doi.org/10.1016/j.jinsphys.2011.03.014

PMid:21435341

Ragini S.T.R., and Anil K.S.,2019, Validation of reference genes for qRT-PCR data normalisation in lentil (Lens culinaris) under leaf developmental stages and abiotic stresses, Physiol. Mol. Biol. Pla., 25(1): 123-134

https://doi.org/10.1007/s12298-018-0609-1

PMid:30804635 PMCid:PMC6352542

Stamova B.S., Apperson M., WalkerW.L. , TianY., Xu H., Adamczy P., Zhan X.H., Liu D.Z., Ander B.P., Liao I.H., Gregg J.P., Turner R.J., Jickling G., Lit L., and Sharp F.R., 2009, Identification and validation of suitable endogenous reference genes for gene expression studies in human peripheral blood, BMC Med. Genomics, 2(1): 1-13

https://doi.org/10.1186/1755-8794-2-49

PMid:19656400 PMCid:PMC2736983

Song H., Dang X., He Y.Q., Zhang T., and Wang H.Y., 2017, Selection of housekeeping genes as internal controls for quantitative RT-PCR analysis of the veined rapa whelk (Rapana venosa), Peer. J., 5: e3398

https://doi.org/10.7717/peerj.3398

PMid:28584723 PMCid:PMC5455708

Su X.Y., Shi Y.B., Yang X. M., Wang G.B., and Cao F.L., 2019, Selection and validation of reference genes for quantitative real-time PCR analysis in Ginkgo biloba, Zhiwu Shengli Xuebao (Plant Physiology Communications), 55(6): 875-882 
Tree Genetics and Molecular Breeding 2020, Vol.10, No.3, 1-7

http://genbreedpublisher.com/index.php/tgmb

Tashiro R.M., Philips J.G., and Winefeld C.S., 2016, Identifcation of suitable grapevine reference genes for qRT-PCR derived from heterologous species, Mol. Genet. Genomics., 291(1): 483-492

https://doi.org/10.1007/s00438-015-1081-z

PMid:26129768

Tong Z.G., Gao Z., Wang F., Zhou J., and Zhang Z., 2009, Selection of reliable reference genes for gene expression studies in peach using real-time PCR, BMC Mol. Biol., 10(1): 71

https://doi.org/10.1186/1471-2199-10-71

PMid:19619301 PMCid:PMC3224724

Wang A.Y., Cao T.F., Lv J.S., and Cong M.,2019, Selection of reference genes by quantitative Real-Time PCR for Ruditapes philippinarum exposed to Nitrite, Shengtai Duli Xuebao (Asian Journal of Ecotoxicology), 14(1): 153-160

Xiao Z., Sun X.B., Liu X.Q., Li C., He L., Chen S.P., and Su J.L., 2016, Selection of reliable reference genes for gene expression studies on Rhododendron molle G. Don, Front Plant Sci., 7: 1547

https://doi.org/10.3389/fpls.2016.01547

Xiao Z., Su J., Sun X., Li C., He L.S., Cheng S.P., and Liu X.Q., 2018, De novo transcriptome analysis of rhododendron molle G. Don flowers by Illumina sequencing, Genes Genom., 40(6): 591-601

https://doi.org/10.1007/s13258-018-0662-8

PMid:29892944

Yan H., Tang X.J., Huang H.Q., Zhang Y., and Dai S.L., 2015, Transcriptomic analyses reveal species-specific light-induced anthocyanin biosynthesis in chrysanthemum, BMC Genomics, 16(1): 202

https://doi.org/10.1186/s12864-015-1428-1

PMid:25887322 PMCid:PMC4404602

Zhang X.Z., 2013, Screening for lipid-rich mutants of Chlamydomonas rinhardtii and analysis of transcription level of key genes in lipid metabolism, Thesis for M.S., Ocean University Of China

Zhang M.C., 2019, Selection of reference genes for gene expression in Rhododendron delavayi Franch. Thesis for M.S., Yunnan University

Zhou J.F., Liu T.T., Zhang H.Q., Zheng G.J., and Yao G.M., 2017, Anti-inflammatory grayanane diterpenoids from the leaves of Rhododendron molle, J. Nat. Prod., 81(1): 151

https://doi.org/10.1021/acs.jnatprod.7b00799

PMid:29272126 